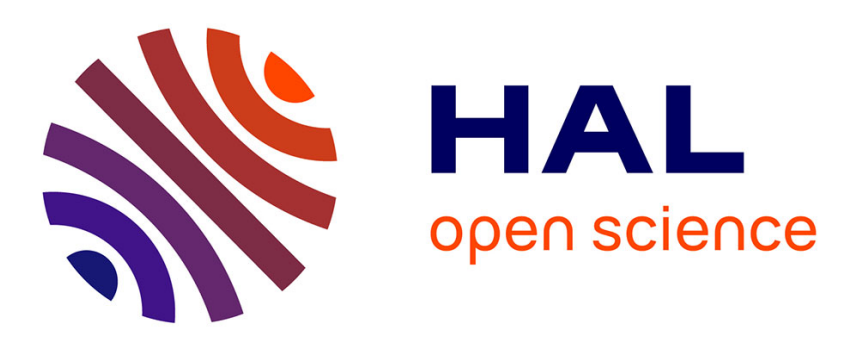

\title{
Kinetics and mechanism of the reaction of ammonium persulfate with ferulic acid and sugar-beet pectins
}

\author{
J.F. Thibault, C. Garreau, D. Durand
}

\section{To cite this version:}

J.F. Thibault, C. Garreau, D. Durand. Kinetics and mechanism of the reaction of ammonium persulfate with ferulic acid and sugar-beet pectins. Carbohydrate Research, 1987, 163, pp.15-27. hal02727510

\section{HAL Id: hal-02727510 \\ https://hal.inrae.fr/hal-02727510}

Submitted on 2 Jun 2020

HAL is a multi-disciplinary open access archive for the deposit and dissemination of scientific research documents, whether they are published or not. The documents may come from teaching and research institutions in France or abroad, or from public or private research centers.
L'archive ouverte pluridisciplinaire HAL, est destinée au dépôt et à la diffusion de documents scientifiques de niveau recherche, publiés ou non, émanant des établissements d'enseignement et de recherche français ou étrangers, des laboratoires publics ou privés. 
Elsevier Science Publishers B.V., Amsterdam - Printed in The Netherlands

\title{
KINETICS AND MECHANISM OF THE REACTION OF AMMONIUM PER- SULFATE WITH FERULIC ACID AND SUGAR-BEET PECTINS
}

\author{
Jean-François Thibault, Carole Garreau, \\ Laboratoire de Biochimie et Technologie des Glucides, Institut National de la Recherche Agronomique, \\ Rue de la Géraudière, 44072 Nantes (France) \\ AND DOMINIQUE DURAND \\ Laboratoire de Chimie et Physicochimie Macromoléculaire, Unité Associée au C.N.R.S., Université du \\ Maine, Route de Laval, 72017 Le Mans (France)
}

(Received May 28th, 1986; accepted for publication, December 22nd, 1986)

\section{ABSTRACT}

The actions of ammonium persulfate on (feruloylated) sugar-beet pectins and ferulate have been studied by spectrophotometry, viscometry, ${ }^{1} \mathrm{H}$-n.m.r. spectroscopy, and gel-permeation chromatography. The reactions followed a pseudo-firstorder law with respect to pectin and ferulate, whereas the order with respect to ammonium persulfate was unity for pectins and varied from 0.5 to $>2$ for ferulate. The rate constants mainly varied with the $\mathrm{pH}$ of the reaction mixture and there was an optimum at 3.8-5.7 for the gelation of the pectins. The results ruled out a simple condensation process between two ferulates (or feruloyl residues linked to the pectins) and suggested a free-radical polymerisation reaction.

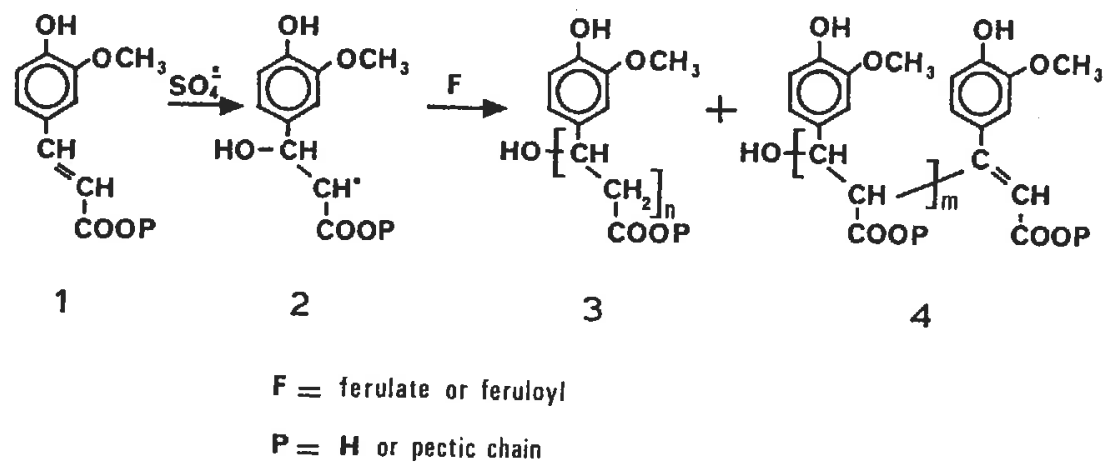

INTRODUCTION

Pectins are generally extracted from such by-products as apple marks and citrus peels ${ }^{1}$. Attempts to use sugar-beet pulps as a raw material have failed, in 
spite of their high content of pectins, because they have poor gelling qualities that have been ascribed to acetylation of the rhamnogalacturonan backbone ${ }^{2}$. Another distinctive feature of sugar-beet pectins is that they contain feruloyl groups attached to the neutral sugar side-chains $s^{3,4}$. This substitution led to the proposal ${ }^{5}$ of a third way of gelation of sugar-beet pectins, in addition to classical calcium gels of "low methoxyl" pectins and sugar-acid gels of "high-methoxyl" pectins". Thus, sugarbeet pectins can be cross-linked through their feruloyl groups and afford gels if the pectin concentration is $>\sim 1 \%$. Ammonium persulfate and hydrogen peroxideperoxidase are effective agents for this cross-linking reaction ${ }^{5,6}$. The effect of ammonium persulfate has been investigated and some evidence was obtained for the involvement of free radicals ${ }^{6}$.

We now report on the kinetics of the reactions of persulfate with sugar-beet pectins and ferulate.

\section{MATERIALS AND METHODS}

Materials. - Sugar-beet pectins were extracted and characterised as previously described ${ }^{6,7}$. The acid form was obtained by percolation through Amberlite IR-120 $\left(\mathrm{H}^{+}\right)$resin and the capacity was determined by conductimetric titrations. Calcium and sodium forms were obtained by exact neutralisation with calcium and sodium hydroxide, respectively. Ferulic acid (4-hydroxy-3-methoxycinnamic acid) was solubilised by treatment with $0.1 \mathrm{M}$ sodium hydroxide to $\mathrm{pH} 6$.

Kinetic measurements. - Solutions (thermostated to $\pm 0.1^{\circ}$ ) containing known quantities of ammonium persulfate and sugar-beet pectin or ferulate were separately mixed, and the rate of disappearance of ferulate or of feruloyl residues was followed spectrophotometrically. Periodically, aliquots were mixed with glycine-sodium hydroxide buffer $(\mathrm{pH} 10$; final molarity, $0.066 \mathrm{M})$ and the absorbances at 375 (pectin) and $345 \mathrm{~nm}$ (ferulate) were recorded. The molar extinction coefficient for feruloyl ester is $31,600 \mathrm{M}^{-1} \cdot \mathrm{cm}^{-1}$ and the value for ferulate under these conditions is $19,600 \mathrm{M}^{-1} . \mathrm{cm}^{-1}$. Some reactions were followed to $>80 \%$ conversion.

Enzymic degradation of pectin. - Aqueous $1 \%$ pectin was incubated at $30^{\circ}$ for $16 \mathrm{~h}$ with a purified endo-polygalacturonase ${ }^{9}$ (EC 3.2.1.15) (2 nkat $/ \mathrm{mg}$ of pectin). The extent of degradation was determined on the basis of the increase in reducing power ${ }^{10}$ and the decrease in viscosity (Ostwald viscometer; solvent flowtime, $80 \mathrm{~s})$.

Gel-permeation chromatography of modified ferulate. - Ferulate ( $70 \mathrm{~mm})$ was treated at room temperature for $5 \mathrm{~h}$ with $0.18 \mathrm{M}$ ammonium persulfate. The mixture was evaporated to dryness, the residue was extracted with methanol, and an aliquot $(100 \mu \mathrm{L})$ of the extract was injected into each of a set of four columns $(0.77 \times 60$ $\mathrm{cm})$ packed with $\mu$-Styragel $100 \AA$ (Polymer Laboratory) and eluted with tetrahydrofuran at $20^{\circ}$ and $0.3 \mathrm{~mL} / \mathrm{min}$. The effluent was monitored with a Waters differential refractometer. The chromatographic system was calibrated using $n$ alkanes $^{11,12}$. 
${ }^{1} H$-N.m.r. spectra. - These were recorded at $60 \mathrm{MHz}$ on solutions in $\mathrm{CD}_{3} \mathrm{OD}$ (internal $\mathrm{Me}_{4} \mathrm{Si}$ ) at room temperature. The modification of ferulate was carried out as described above. The notation of protons was the same as in ref. 13.

Viscometry. An automatic Ostwald viscometer (Fica, France) of $\phi 0.58 \mathrm{~mm}$ was used as previously described ${ }^{6}$. The flow-times were recorded as a function of the time of reaction, and the results are expressed as the ratio of the maximum reduced viscosity to the initial reduced viscosity.

RESULTS

Reaction order with respect to ferulate and pectins. - The action of ammonium persulfate on ferulate was followed spectrophotometrically (Fig. 1). Ferulate initially had $\lambda_{\max } \sim 345 \mathrm{~nm}$ with a shoulder at $\sim 300 \mathrm{~nm}$. When persulfate ions were added, the absorbance decreased and all the curves passed through an isosbestic point if the time of reaction was $<10 \mathrm{~h}$. Fig. 1 also indicates that a limit spectrum was obtained, and the absorbance at $345 \mathrm{~nm}$ represented $18.4 \pm 0.9 \%$ of the initial value, as measured at $345 \mathrm{~nm}$ with various concentrations of ammonium persulfate and ferulate and various temperatures. Pectins have been reported to have $\lambda_{\max } 375 \mathrm{~nm}$ under these conditions, due to the bathochromic effect of the ester linkage ${ }^{13,14}$. The products of the reaction of ammonium persulfate on pectins also absorbed at $375 \mathrm{~nm}$, with an absorbance representing $19.6 \pm 1.3 \%$ of the initial value.

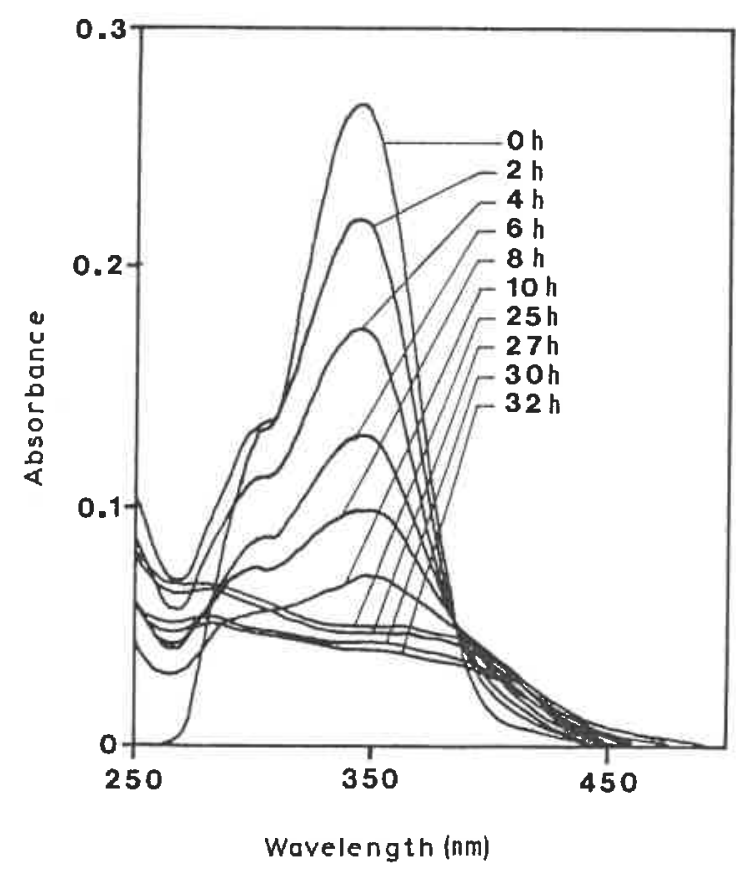

Fig. 1. Changes with time of the u.v. spectra of $0.05 \mathrm{~mm}$ ferulate in $0.02 \mathrm{M}$ ammonium persulfate at $25^{\circ}$; the solution $(1 \mathrm{~mL})$ was mixed with $0.2 \mathrm{M}$ glycine-sodium hydroxide buffer $(\mathrm{pH} 10,3 \mathrm{~mL})$ and the spectra were recorded immediately. 
No further decrease in the limit absorbance was obtained on the addition of an excess of ammonium persulfate to either ferulate or pectin, indicating that the reactions were complete. Since the products absorbed at the measuring wavelength, it was not possible to relate directly the absorbances to the residual concentration in ferulate or in pectin-linked feruloyl groups. It can be shown ${ }^{15}$ that

$$
(F)_{t}=(F)_{0} \times \frac{A_{t}-A_{\infty}}{A_{0}-A_{\infty}}
$$

where $(F)_{\mathrm{t}}$ and $(F)_{0}$ are the concentrations of ferulate or feruloyl groups at time $t$ and initially, respectively, and $A_{0}, A_{t}$, and $A_{\infty}$ are absorbances initially, at time $t$, and at infinity, respectively. Equation 1 is valid whatever the form of the kinetic equation ${ }^{15}$ and is independent of the molar extinction coefficient of the products. Therefore, equations 2 and 3 apply to first- and second-order reactions, respectively, where $k_{\text {app }}$ is the apparent rate constant.

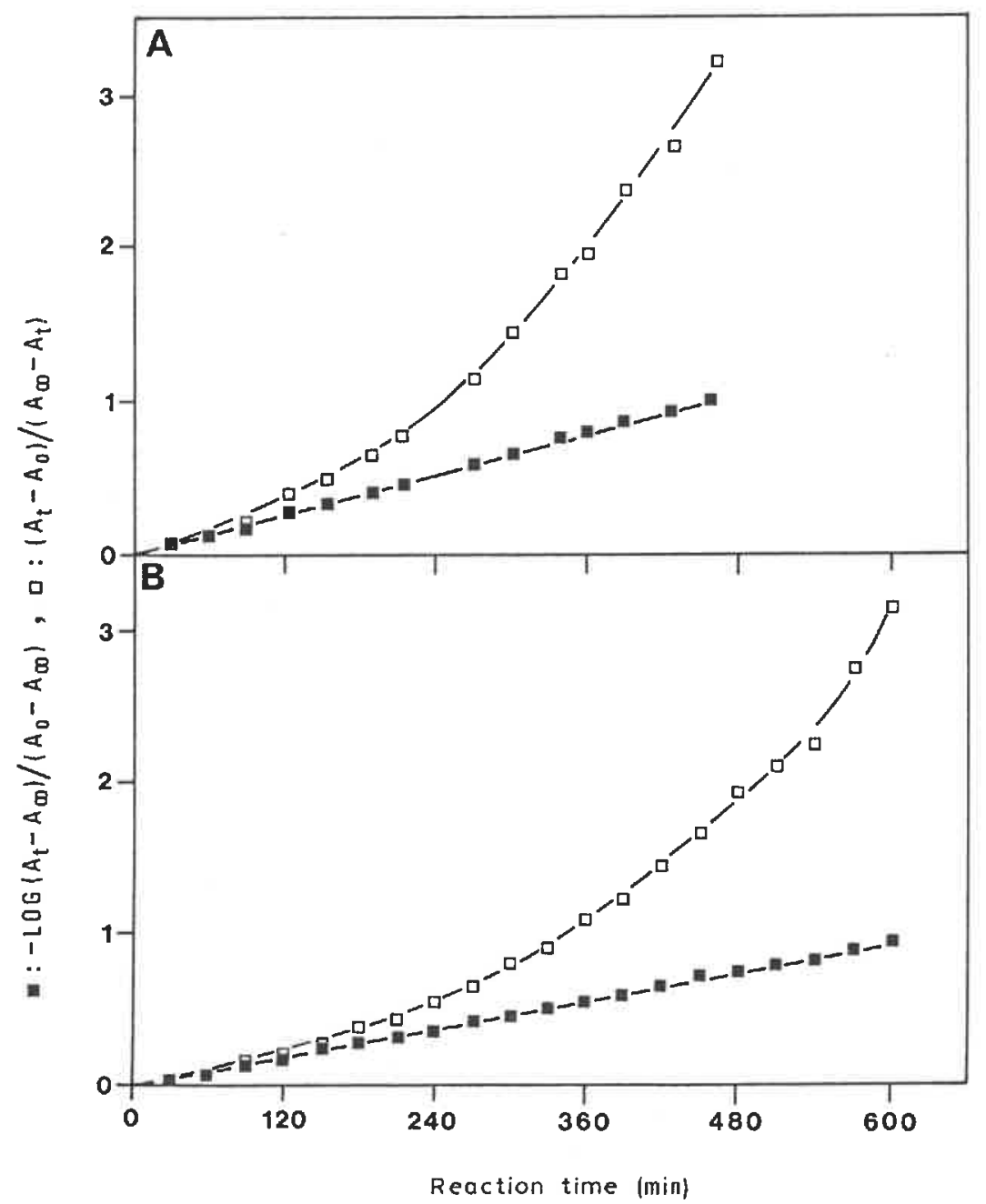

Fig. 2. Kinetics of the action of ammonium persulfate on $A$, sugar-beet pectin $(0.44 \%$ in $0.01 \mathrm{M}$ ammonium persulfate at $\left.40^{\circ}\right)$; and $B$, ferulate $\left(0.25 \mathrm{mM}\right.$ in $0.05 \mathrm{M}$ ammonium persulfate at $\left.25^{\circ}\right)$; analysed in terms of pseudo-first order $(\square)$ and of pseudo-second-order $(\square)$ reactions with respect to feruloyl residues and ferulate, respectively. 


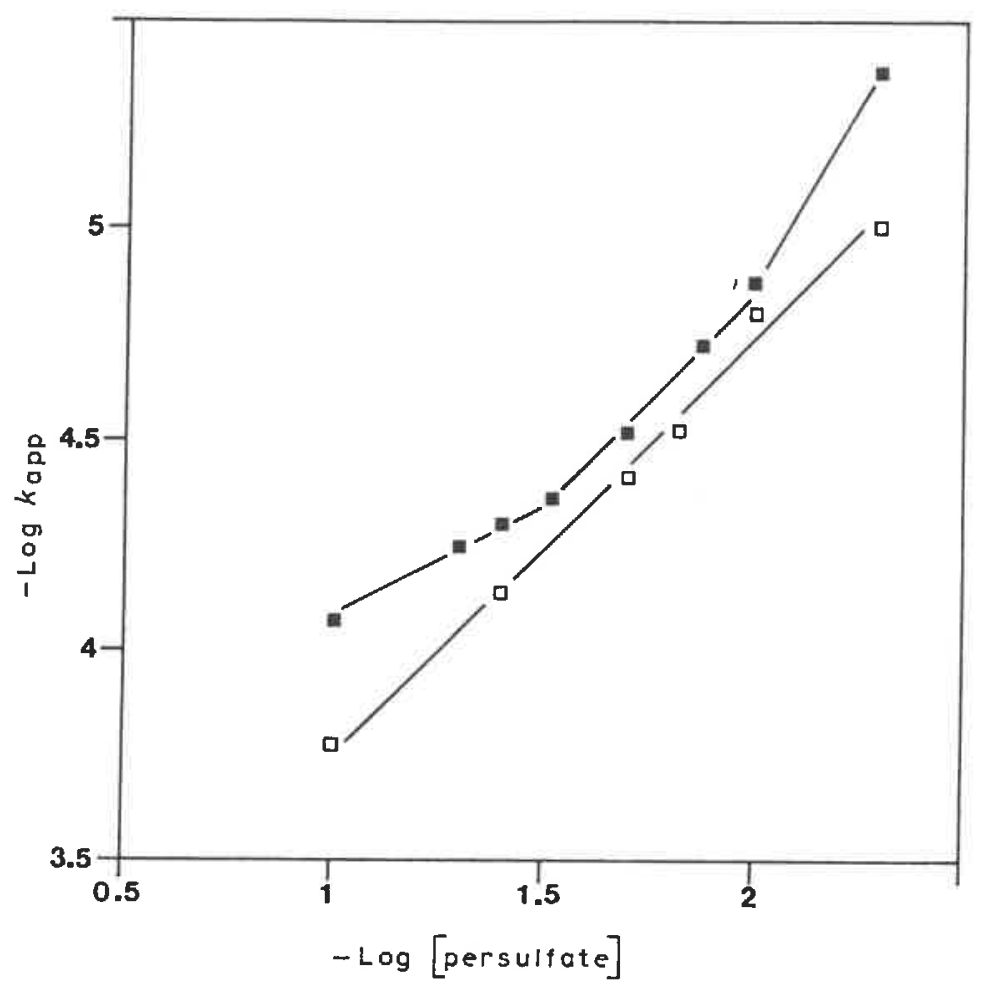

Fig. 3. Dependence of the apparent rate constant $\left(k_{\text {app }}\right)$ on the concentration of ammonium persulfate at $25^{\circ}(\mathbf{m}, 0.25 \mathrm{~mm}$ ferulate; $\square, 0.44 \%$ of pectin).

$$
\begin{aligned}
& \log \frac{A_{t}-A_{\infty}}{A_{0}-A_{\infty}}=-k_{\text {app }} t \\
& \frac{A_{t}-A_{0}}{A_{t}-A_{\infty}}=-k_{\text {app }}(F)_{0} t
\end{aligned}
$$

Both representations are shown in Fig. 2 for typical reactions of ferulate and pectins in the presence of a large excess (54-200-fold) of ammonium persulfate. Each reaction is pseudo-first-order with respect to ferulate and pectin; the extents of reaction were $86.3 \%$ and $95.8 \%$, respectively.

Influence of ammonium persulfate concentration. - For solutions containing a constant amount of pectin ( $0.44 \%$, corresponding to $0.19 \mathrm{~mm}$ feruloyl groups) or ferulate $(0.25 \mathrm{mM})$ at $25^{\circ}$ and $0.005-0.1 \mathrm{M}$ ammonium persulfate, a $\log / \mathrm{log}$ plot (Fig. 3) of $k_{\text {app }}$ and ammonium persulfate concentration demonstrated that the reaction with pectin is of pseudo-first-order with respect to ammonium persulfate and that the $k_{2}$ value $\left(k_{2}=k_{\text {app }}\right.$ ( $\left.[\text { ammonium persulfate }]_{0}\right)$ was $18.3 \times 10^{-4} \mathrm{M}^{-1} \cdot \mathrm{s}^{-1}$.

In contrast, no simple relation was obtained for ferulate; the orders of the reaction were $\sim 0.5, \sim 1$, and $>2$ for $\geqslant 0.03 \mathrm{M}, 0.03-0.01 \mathrm{M}$, and $\leqslant 0.01 \mathrm{M}$ ammonium persulfate, respectively. 
TABLE I

EFFECT OF FERULIC ACID CONCENTRATION OF THE APPARENT RATE CONSTANT $\left(k_{\text {app }}\right)$ FOR TWO CONCENTRATIONS OF AMMONIUM PERSULFATE AT $25^{\circ}$

\begin{tabular}{|c|c|c|c|c|c|}
\hline & \multicolumn{5}{|c|}{ Ferulic acid (mM) } \\
\hline & 0.5 & 0.4 & 0.25 & 0.1 & 0.05 \\
\hline \multicolumn{6}{|l|}{$0.1 \mathrm{M}$ Persulfate } \\
\hline$k_{\mathrm{app}} \times 10^{5}\left(\mathrm{~s}^{-1}\right)$ & 8.6 & 8.5 & 8.5 & 8.4 & \\
\hline Initial $\mathrm{pH}^{a}$ & 2.95 & 2.83 & 2.78 & 2.75 & \\
\hline pH after $24 \mathrm{~h}$ & 2.64 & 2.61 & 2.64 & 2.68 & \\
\hline \multicolumn{6}{|l|}{$0.05 \mathrm{M}$ Persulfate } \\
\hline$k_{\text {app }} \times 10^{5}\left(\mathrm{~s}^{-1}\right)$ & 8.7 & 8.8 & 7.6 & 8.6 & 8.6 \\
\hline Initial $\mathrm{pH}^{a}$ & 4.11 & 3.91 & 3.66 & 3.46 & 3.40 \\
\hline $\mathrm{pH}$ after $24 \mathrm{~h}$ & 3.13 & 3.11 & 3.15 & 3.23 & 3.28 \\
\hline
\end{tabular}

${ }^{a}$ Measured just after the addition of persulfate ions.

Effect of concentration of ferulate and of pectin. - For a given ammonium persulfate concentration ( $>18$-fold excess), the rate of disappearance of ferulate at $25^{\circ}$ was independent of the concentration of ferulate in the range $0.05-0.5 \mathrm{mM}$, as shown by the constancy of the $k_{\text {app }}$ values (Table I). Since the order of the reaction with respect to ammonium persulfate concentration was not well-defined, the overall rate constants were not calculated, but it is clear that they depend on the ammonium persulfate concentration.

The results obtained with pectins for three concentrations of ammonium persulfate are listed in Table II. In each reaction, the apparent rate constant was roughly constant when the pectin concentrations were $>\sim 0.4 \%$. The corresponding second-order rate constant increased slightly with decreasing concentrations of ammonium persulfate: $10.9 \pm 0.6,12.7 \pm 1.9$, and $15.7 \pm 0.6 \times 10^{-4} \mathrm{M}^{-1} \cdot \mathrm{s}^{-1}$ for $0.1,0.04$, and $0.01 \mathrm{M}$ ammonium persulfate, respectively. The rate constants increased for concentrations of pectin $<0.4 \%$.

Variations of $\mathrm{pH}$. - For reactions involving various concentrations of ammonium persulfate, ferulate, and pectin (Tables I-III), measurement of the $\mathrm{pH}$ initially and after $24 \mathrm{~h}$ revealed a decrease with decreasing concentrations of pectin or ferulate, and with increasing concentrations in ammonium persulfate. Lower $\mathrm{pH}$ values and more marked shifts were generally obtained with ferulates than with pectins.

Influence of enzymic depolymerisation of the pectins. - The sugar-beet pectin was degraded by an endo-polygalacturonase which hydrolyses glycosidic linkages of the rhamnogalacturonan backbone ${ }^{9}$. The extent of hydrolysis was only $2.3 \%$ because the action of the enzyme was hindered by the presence of methyl ${ }^{9}$ and acetyl $^{4}$ groups in the pectin. Nevertheless, due to its endo-character, the enzyme decreased the reduced viscosity of a $0.25 \%$ pectin solution by $54 \%$. The kinetic 
TABLE II

EFFECT OF PECTIN CONCENTRATION ON THE RATE CONSTANTS FOR THREE CONCENTRATIONS OF AMMONIUM PERSULFATE AT $25^{\circ}$

\begin{tabular}{|c|c|c|c|c|c|c|c|}
\hline & \multicolumn{7}{|c|}{$\operatorname{Pectin}(\%)$} \\
\hline & 1.2 & 1.0 & 0.8 & 0.6 & 0.4 & 0.2 & 0.1 \\
\hline & \multicolumn{7}{|c|}{ Feruloyl groups (mM) } \\
\hline & 0.55 & 0.45 & 0.33 & 0.26 & 0.17 & 0.09 & 0.04 \\
\hline \multicolumn{8}{|l|}{$0.1 \mathrm{M}$ Persulfate } \\
\hline$k_{\text {app }} \times 10^{5}\left(\mathrm{~s}^{-1}\right)$ & 10.4 & 10.3 & 11.2 & 11.6 & 16.3 & 22.0 & 32.3 \\
\hline$k_{2} \times 10^{4}\left(\mathrm{M}^{-1} \cdot \mathrm{s}^{-1}\right)$ & 10.4 & 10.3 & 11.2 & 11.6 & 16.3 & 22.0 & 32.3 \\
\hline Initial $\mathrm{pH}^{a}$ & 3.68 & 3.60 & 3.56 & 3.50 & 3.32 & 3.00 & 2.86 \\
\hline $\mathrm{pH}$ after $24 \mathrm{~h}$ & 2.95 & 2.80 & 2.54 & 2.54 & 2.30 & 2.20 & n.d. ${ }^{b}$ \\
\hline \multicolumn{8}{|l|}{$0.04 \mathrm{M}$ Persulfate } \\
\hline$k_{\mathrm{app}} \times 10^{5}\left(\mathrm{~s}^{-1}\right)$ & 5.0 & 4.5 & 4.6 & 5.0 & 6.4 & 10.1 & 16.7 \\
\hline$k_{2} \times 10^{4}\left(\mathrm{M}^{-1} \cdot \mathrm{s}^{-1}\right)$ & 12.5 & 11.3 & 11.4 & 12.5 & 16.0 & 25.2 & 41.7 \\
\hline Initial $\mathrm{pH}^{a}$ & 4.20 & 4.13 & 4.03 & 4.00 & 3.83 & 3.50 & 3.36 \\
\hline \multirow[t]{5}{*}{$\mathrm{pH}$ after $24 \mathrm{~h}$} & 3.60 & 3.53 & 3.48 & 3.43 & 3.34 & 2.85 & n.d. \\
\hline & \multicolumn{7}{|c|}{ Pectin (\%) } \\
\hline & 1.2 & 1.0 & 0.8 & 0.6 & 0.44 & 0.25 & \\
\hline & \multicolumn{7}{|c|}{ Feruloyl groups (mM) } \\
\hline & 0.55 & 0.45 & 0.33 & 0.26 & 0.19 & 0.11 & \\
\hline \multicolumn{8}{|l|}{$0.01 \mathrm{M}$ Persulfate } \\
\hline$k_{\text {app }} \times 10^{5}\left(\mathrm{~s}^{-1}\right)$ & 1.7 & 1.5 & 1.5 & 1.5 & 1.6 & 2.1 & \\
\hline$k_{2} \times 10^{4}\left(\mathrm{M}^{-1} \cdot \mathrm{s}^{-1}\right)$ & 16.7 & 15.3 & 15.4 & 15.5 & 15.6 & 20.6 & \\
\hline Initial $\mathrm{pH}^{a}$ & 5.10 & 5.08 & 5.06 & 5.01 & 4.95 & 4.77 & \\
\hline $\mathrm{pH}$ after $24 \mathrm{~h}$ & 4.31 & 4.31 & 4.32 & 4.30 & 4.26 & 4.17 & \\
\hline
\end{tabular}

${ }^{a}$ Measured just after the addition of persulfate. ${ }^{b}$ Not determined.

TABLE III VARIATION OF THE $\mathrm{pH}$ OF MIXTURES CONTAINING $0.25 \mathrm{mM}$ FERULIC ACID OR $0.44 \%$ OF PECTIN AND
AMMONIUM PERSULFATE AT $25^{\circ}$

\begin{tabular}{llllll}
\multirow{2}{*}{ Ammonium persulfate $(\mathrm{M})$} & \multicolumn{3}{l}{ Ferulic acid } & \multicolumn{2}{l}{ Pectin } \\
\cline { 2 - 3 } & Initial $p H^{a}$ & pH after 24 $h$ & & Initial $p H^{a}$ & pH after $24 h$ \\
\hline 0.1 & 2.78 & 2.64 & 3.32 & 2.30 \\
0.05 & 3.04 & 2.84 & n.d. & n.d. \\
0.04 & 3.16 & 2.91 & 4.26 & 3.61 \\
0.03 & 3.34 & 3.00 & n.d. & n.d. \\
0.02 & 3.66 & 3.15 & 4.63 & 4.04 \\
0.015 & 3.95 & 3.25 & 4.74 & 4.17 \\
0.01 & 4.05 & 3.33 & 4.95 & 4.37 \\
0.005 & 4.55 & 3.72 & 5.12 & 4.56 \\
\hline
\end{tabular}

${ }^{a}$ Measured just after the addition of persulfate. ${ }^{b}$ Not determined. 
TABLE IV

SECOND-ORDER RATE CONSTANTS FOR THE REACTION OF AMMONIUM PERSULFATE WITH PECTINS AT $25^{\circ}$

\begin{tabular}{|c|c|c|c|c|}
\hline $\begin{array}{l}\text { Pectin } \\
\text { concentration (\%) }\end{array}$ & $\begin{array}{l}\text { Experimental } \\
\text { conditions }\end{array}$ & $\begin{array}{l}\text { Persulfate } \\
(\mathrm{M})\end{array}$ & $\begin{array}{l}\mathbf{k}_{2} \times 10^{4} \\
\left(\mathrm{M}^{-1} \cdot s^{-1}\right)\end{array}$ & $\begin{array}{l}\text { Initial } \\
p H\end{array}$ \\
\hline \multirow{3}{*}{1} & \multirow{3}{*}{ Enzyme-degraded } & 0.1 & 8.7 & 4.10 \\
\hline & & 0.04 & 12.3 & 4.50 \\
\hline & & 0.01 & 18.3 & 4.86 \\
\hline \multirow{3}{*}{0.4} & Sodium form & 0.01 & 8.6 & 5.27 \\
\hline & Sodium form $+0.05 \mathrm{M} \mathrm{NaCl}$ & 0.01 & 7.5 & 5.66 \\
\hline & Sodium form $+0.2 \mathrm{M} \mathrm{NaCl}$ & 0.01 & 9.0 & 5.86 \\
\hline \multirow[t]{2}{*}{0.6} & Sodium form $+0.05 \mathrm{M} \mathrm{NaCl}$ & 0.01 & 8.5 & 5.54 \\
\hline & Sodium form $+0.2 \mathrm{M} \mathrm{NaCl}$ & 0.01 & 8.5 & 5.50 \\
\hline
\end{tabular}

study of the action of ammonium persulfate on this degraded pectin showed (Table IV) that the second-order rate constants were not significantly changed (cf. Table II).

Influence of $p H$ and ionic strength. - Previous work on pectins ${ }^{6}$ demonstrated that the addition of acetate, disodium hydrogenphosphate, sodium dihydrogenphosphate, and trisodium citrate ions completely inhibited the cross-linking reaction, at least at $\mathrm{pH}>5$. The present study indicated that the use of acetate buffer $(0.1 \mathrm{M})$ at $\mathrm{pH} 4$ and 5 does not lead to any increase in viscosity during $17 \mathrm{~h}$ of reaction. The rate constant $k_{2}$ determined at $\mathrm{pH} 3$ under buffered $(0.1 \mathrm{M}$ citrate-hydrochloric acid) and unbuffered conditions gave values of $2.91 \times 10^{-3}$ and $29.3 \times$ $10^{-3} \mathrm{M}^{-1} \cdot \mathrm{s}^{-1}$, respectively, indicating inhibition of the reaction by such ions. Therefore, the influence of $\mathrm{pH}$ was investigated by changing the degree of neutralisation of the pectin, keeping in mind that this may also change the conformation of the polymer. The variation of the second-order rate constant with the $\mathrm{pH}$ is shown in Fig. 4. There was a profound influence of $\mathrm{pH}$ on the reaction rate, since the value of $k_{2}$ is $9 \times 10^{-4} \mathrm{M}^{-1} . \mathrm{s}^{-1}$ for fully ionised pectin and increased to $3 \times 10^{-2} \mathrm{M}^{-1} . \mathrm{s}^{-1}$ for pectin in the acid form. This variation, determined for 0.4 and $1 \%$ of pectin, was independent of the nature of the counterion (sodium or calcium). Furthermore, the addition of 0.05 or $0.2 \mathrm{M} \mathrm{NaCl}$ to a reaction mixture containing fully ionised pectins did not change the value of the rate constant (Table IV).

The gelation of aqueous $1 \%$ pectin, as studied by viscometry (Fig. 4), did not increase with decreasing $\mathrm{pH}$ in parallel with the increase of the rate constant. In contrast, an optimum range was found, between $\mathrm{pH} 3.8$ and 5.7, where gelation occurred with the setting time increasing with increasing $\mathrm{pH}: 137,136,154,254$, and $1620 \mathrm{~min}$ for $\mathrm{pH}$ values of $3.8,4,4.12,4.77$, and 5.70, respectively. Beyond these two $\mathrm{pH}$ values, only increases in viscosity were found.

Influence of temperature. - The influence of temperature $\left(20-40^{\circ}\right)$ was studied on mixtures containing $0.44 \%$ of pectin and $0.01 \mathrm{M}$ ammonium persulfate, 


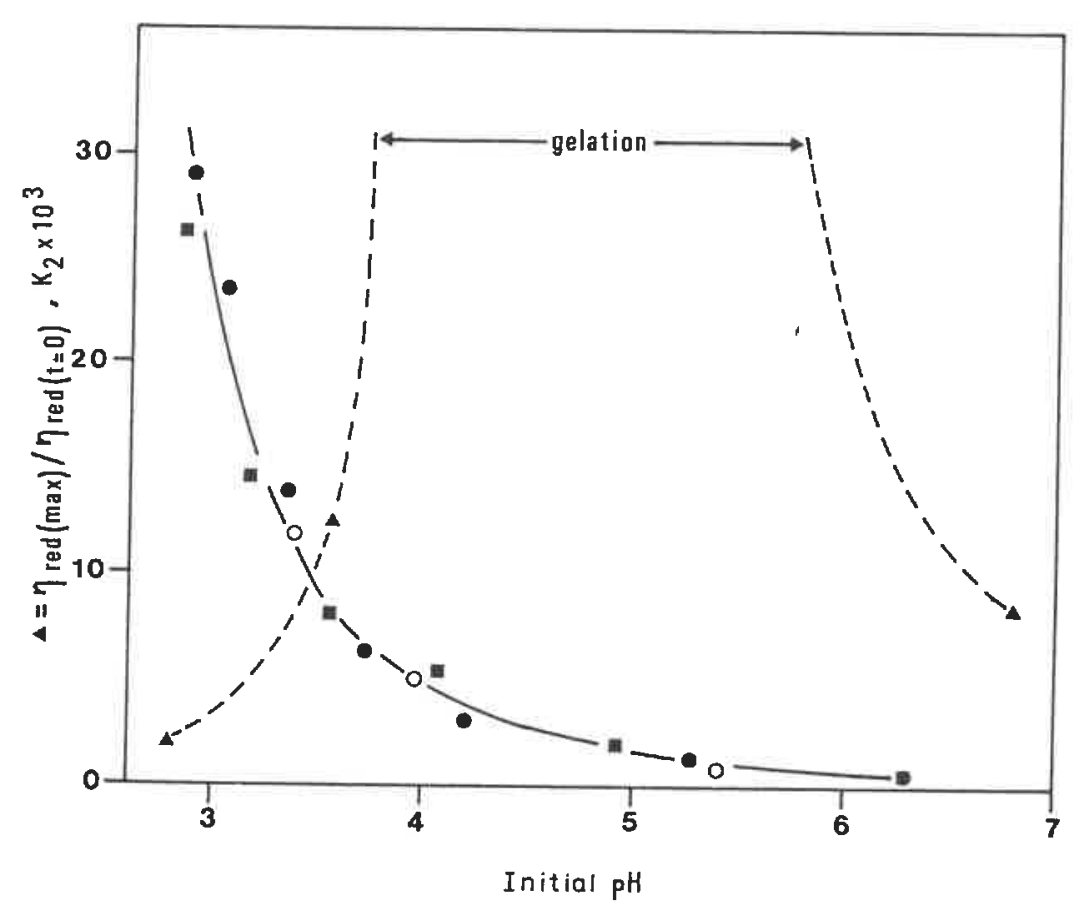

Fig. 4. Effect of the initial $\mathrm{pH}$ value on the second-order rate constant for pectins $[\bullet, 0.44 \%$ of pectin $\left(\mathrm{Na}^{+}\right) ; \mathrm{E}, 1 \%$ of pectin $\left(\mathrm{Na}^{+}\right) ; O, 0.44 \%$ of pectin $\left.\left(\mathrm{Ca}^{2+}\right)\right]$ and on the ratio $(\Delta)$ of maximum reduced viscosity to initial reduced viscosity of a $1 \%$ solution of pectin $\left(\mathrm{Na}^{+}\right)$in the presence of $0.01 \mathrm{M}$ ammonium persulfate at $25^{\circ}$.

or ferulate $(0.25 \mathrm{mM})$ and 0.1 and $0.02 \mathrm{M}$ ammonium persulfate. From a plot of $k_{\text {app }}$ versus $1000 / T$ (Fig. 5) according to the Arrhenius equation, an energy activation of $75 \mathrm{~kJ} . \mathrm{mol}^{-1}$ was obtained.

${ }^{1} H$-N.m.r. spectroscopy and gel-permeation chromatography of modified ferulate. - The ${ }^{1} \mathrm{H}$-n.m.r. spectrum of ferulate in $\mathrm{CD}_{3} \mathrm{OD}$ contained signals ${ }^{13}$ at $\delta$ 6.31 and $7.61(=\mathrm{CH}), \sim 7$ (aromatic protons), and $3.83(\mathrm{OMe})$. The action of ammonium persulfate resulted in a complex spectrum (not shown) characterised by a marked decrease of the intensity of the signals for $=\mathrm{CH}$, a marked broadening and poor resolution of the signals for the aromatic protons, and the occurrence of signals at $\delta \sim 4$ which were attributed to tertiary protons. Integration showed that the signals of aromatic protons and of methoxyl protons were in the ratio $1: 1$.

Gel-permeation chromatography (Fig. 6) of the reaction mixture gave a series of peaks corresponding to products of increased molecular weight. Peaks 1-3 corresponded to ferulate and its dimer and trimer, respectively. Peaks $1^{\prime}-3^{\prime}$ were not identified although they could be attributed to slightly modified products 1-3. Products of higher molecular weight were also detected containing up to ten feruloyl residues. 


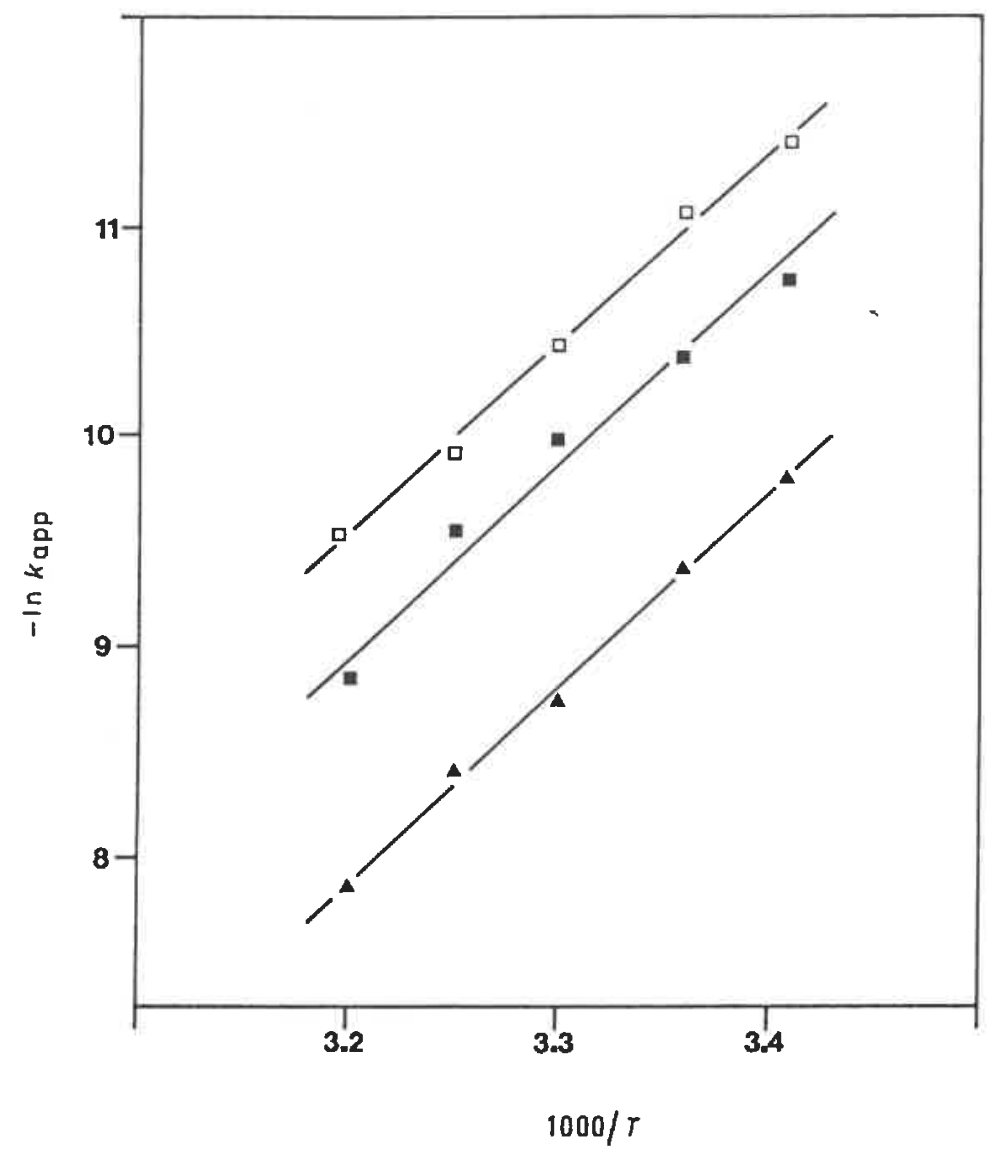

Fig. 5. Arrhenius plots for $0.44 \%$ pectin in $0.01 \mathrm{M}$ ammonium persulfate ( $\square), 0.25 \mathrm{~mm}$ ferulate in $0.02 \mathrm{M}$ ammonium persulfate $(\mathbf{B})$, and $0.25 \mathrm{~mm}$ ferulate in $0.1 \mathrm{M}$ ammonium persulfate $(\mathbf{\Delta})$.

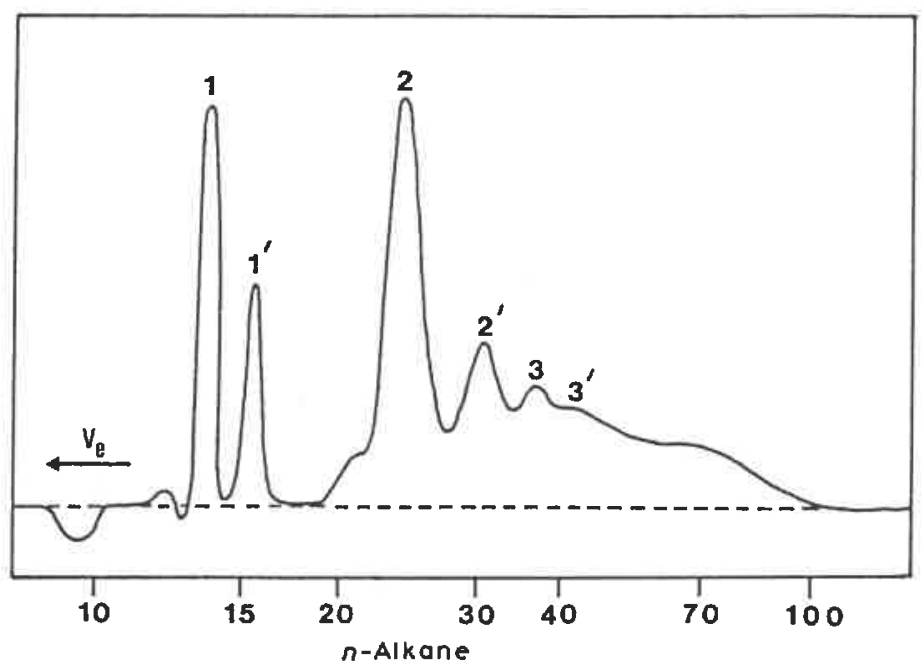

Fig. 6. Gel-permeation chromatography on $\mu$-Styragel of the products of reaction of ferulate with ammonium persulfate. 


\section{DISCUSSION}

The purpose of this paper was to obtain a better understanding of the crosslinking reaction of sugar-beet pectins effected with ammonium persulfate. It is well known that wheat pentosans carry some feruloyl residues that can be modified by some oxidising agents, leading to gelation ${ }^{16}$. Dimerisation involving feruloyl residues on separate macromolecules has been postulated ${ }^{17}$, and demonstrated for tyrosine $^{18}$. In contrast, it has been suggested ${ }^{19}$ that the aromatic nucleus is not involved in the reaction, but that a protein radical adds to the double bond of the feruloyl residue. Cinnamic acids can be photodimerised in the solid-state, producing cyclobutane derivatives ( $\alpha$-truxillic acids or $\beta$-truxinic acids ${ }^{20}$ ). This reaction has been used for photo-cross-linking ${ }^{21}$ cinnamoylated cellulose or polyvinyl, and resembles the persulfate-induced cross-linking of sugar-beet pectins in solution.

The reaction with persulfate ions for sugar-beet pectin followed a first-order law with respect to pectin (or ferulate), which ruled out an intermolecular (i.e., second-order) condensation of feruloyl residues. Since ferulate alone was also cross-linked, the cross-linking of sugar-beet pectin probably involves only the feruloyl residues and not protein which are also present ${ }^{3,4}$

The n.m.r. studies demonstrated that the aromatic nuclei were not modified, but that the double bonds were involved in the reaction. The broadening of the signals from aromatic protons is generally ascribed to a polymerisation process, and this inference accords with the gel-permeation chromatography data which indicated that oligomers of ferulates, with d.p. up to 10 , were produced. Therefore, the mechanism proposed for the reaction of persulfate ions with pectins and ferulates is the sequence $1 \rightarrow 2 \rightarrow 3+4$. The polymerisation of pectin feruloyl groups is probably sterically hindered and results mainly in the formation of dimers.

Previous work ${ }^{6}$ indicated the involvement of free radicals in the reaction. It is well-known ${ }^{22}$ that persulfate ions decompose in aqueous solutions to produce sulfate ion radicals which may react with water to produce the hydroxyl radical and oxygen according to equations $4-6$

$$
\begin{aligned}
& \mathrm{S}_{2} \mathrm{O}_{8}^{2-} \rightarrow 2 \mathrm{SO}_{4}^{-} \\
& \mathrm{SO}_{4}^{-}+\mathrm{H}_{2} \mathrm{O} \rightarrow \mathrm{HO}+\mathrm{HSO}_{4}^{-} \\
& 2 \mathrm{HO} \cdot \rightarrow \mathrm{H}_{2} \mathrm{O}+1 / 2 \mathrm{O}_{2}
\end{aligned}
$$

The reaction could therefore be initiated either by the sulfate ion radical or the hydroxyl radical. Equation 5 may explain the decrease of $\mathrm{pH}$ during the reaction, even if its rate is $l w^{23}$, except under alkaline conditions. Apparently (Tables I-III), a low $\mathrm{pH}$ enhanced the rate of disappearance of ferulate as well as feruloyl groups, and the initial $\mathrm{pH}$ is higher with pectin than with ferulate. These differences in $\mathrm{pH}$ values could be related to the effect of persulfate concentration on the order of reaction with respect to persulfate. It is noteworthy that, for high concentrations of ammonium persulfate, the rate of disappearance of ferulate is proportional to 
ferulate concentration and to the square-root of persulfate concentration, as in classical free-radical polymerisation ${ }^{24}$. The effect of $\mathrm{pH}$ is clearly shown in Fig. 4. Low $\mathrm{pH}$ values favour ${ }^{22}$ non-radical decomposition of persulfate ions and the increase of the rate of disappearance of feruloyl groups under acidic conditions could be due to oxidation of these residues. Analysis of the $\mathrm{pH}$-dependence of the reaction is complicated because pectins are polyelectrolytes which can adopt an extended conformation in a fully ionised state and a coil conformation in the acid form. Nevertheless, the facts that the rate constant for fully ionised pectins is independent of the cation and of the ionic strength of the reaction mixture (which can also affect the efficiency of persulfate) and is not changed by enzymic depolymerisation indicated that the conformation of the polymer did not play an important role in the reaction. Apparently, the $\mathrm{pH}$ is the only factor that influences the rate of reaction and there must be a balance between low $\mathrm{pH}$, which favours oxidation reactions, and neutral or alkaline $\mathrm{pH}$, which may enhance reactions 5 and 6 , leading to a more pronounced decay of the sulfate ion radical and to a rapid decomposition of hydroxyl radical. It is also possible that the hydroxyl radical is less selective than the sulfate ion radical in the proton-abstraction reaction ${ }^{23}$. On the other hand, pectic molecules can be slightly depolymerised by a $\beta$-elimination process under neutral conditions ${ }^{25}$, even at $25^{\circ}$. All of these effects could explain the occurrence of gelation of pectins only in the $\mathrm{pH}$ range 3.8-5.7.

The reaction is apparently inhibited by acetate, phosphate, and citrate ions, but not by polygalacturonate ions. Small ions may act as scavengers for free radicals ${ }^{22}$; for example, persulfate initiation is said to be totally suppressed by oxalate ions ${ }^{26}$, presumably as a result of complex formation. Inhibition by acetate ions has also been reported for the radical polymerisation of acrylic and methacrylic acid salts in aqueous solutions by Kabanov et al. ${ }^{27}$, who also observed a similar $\mathrm{pH}$-dependence of the reaction rate.

The reactions of ammonium persulfate with pectin and ferulate are complex. The order of these reactions with respect to pectin or ferulate is unity, but the values of the rate constants are dependent on experimental conditions and mainly on $\mathrm{pH}$. Clarification of the mechanism of reaction must await determination of the structures of the reaction products and the radicals involved in this reaction.

\section{ACKNOWLEDGMENTS}

We thank Mrs. M. J. Crepeau for technical assistance, and Dr. P. Krausz (C.N.R.S., Institut de Chimie des Substances Naturelles, Gif-sur-Yvette, France) for helpful discussion.

\section{REFERENCES}

1 D. B. Nelson, C. J. B. Smit, And R. R. Wiles, in H. D. Graham (Ed.), Food Colloids, Avi Publishing Co., Westport, 1977, pp. 418-437.

2 E. L. Pippen, R. M. MacCready, ANd H. S. Owens, J. Am. Chem. Soc., 72 (1950) 813-816. 
3 F. M. Rombouts and J.-F. Thibault, Carbohydr. Res., 154 (1986) 177-187.

4 F. M. Rombouts and J.-F. Thibault, Carbohydr. Res., 154 (1986) 189-203.

5 F. M. Rombouts, J.-F. Thibault, And C. Mercier, Fr. Pat. 8,307,208 (1983); Chem. Abstr., 102 (1985) $60,792 u$.

6 J.-F. Thibault and F. M. Rombouts, Carbohydr. Res., 154 (1986) 205-215.

7 F. Michel, J.-F. Thibault, C. Mercier, F. Heitz, and F. Poulllaude, J. Food Sci., 50 (1985) 1499-1500.

8 S. C. FRY, Biochem. J., 203 (1982) 493-504.

9 J.-F. Thibault And C. Mercier, J. Food Biochem., 2 (1978) 379-393.

10 N. Nelson, J. Biol. Chem., 153 (1944) 375-379.

11 P. Blanchard, J. P. Busnel, AND C. M. BRuneau, Spectra 2000, 76 (1982) 29-34.

12 J. P. BUSNEL, Spectra 2000, 104 (1985) 17-20.

13 M. M. SMith AND R. D. HaRTLEY, Carbohydr. Res., 118 (1983) 65-80.

14 L. JURD, Arch. Biochem. Biophys., 66 (1957) 284-288.

15 J. H. Espenson, Chemical Kinetics and Reaction Mechanisms, McGraw-Hill, New York, 1981.

16 H. NeuKom and H. U. MARKWALder, Cereal Foods World, 23 (1978) 374-377.

17 T. Geismann AND H. Neukom, Lebensm.-Wiss. Technol, 6 (1973) 59-62.

18 G. MAtheis AND J. R. WhitAkeR, J. Food Biochem., 8 (1984) 137-162.

19 R. C. Hoseney and J. M. Faubion, Cereal Chem., 58 (1981) 421-424.

20 M. D. Cohen, G. M. J. Schmidt, And F. I. Sonntag, J. Chem. Soc., (1964) 2000-2013.

21 G. A. Delzenne, Eur. Polym. J. Suppl., (1969) 55-91.

22 R. A. M. Thomson, in C. A. Finch (Ed.), Chemistry and Technology of Water-soluble Polymers, Plenum Press, New York, 1983, pp. 31-70.

23 E. Hayon, A. Treinin, AND J. Wilf, J. Am. Chem. Soc., 94 (1972) 47-57.

24 P. J. FloRY, Principles of Polymer Chemistry, Cornell University Press, Ithaca, 1953, pp. 106-177.

25 P. Albersheim, H. Neukom, ANd H. Deuel, Arch. Biochem. Biophys., 90 (1960) 46-51.

26 M. H. Husain, S. N. Misra, ANd R. D. Singh, Makromol. Chem., 179 (1978) 295-300.

27 V. A. Kabanov, D. A. Topchiev, and T. M. Karaputadze, J. Polym. Sci., Polym. Symp., 42 (1973) 173-183. 